\title{
Terminological Field "Surgical Instruments" of German Language as Result of Cognitive Activity of Specialist
}

\author{
Sanya Madzhaeva*, and Tatiana Lukoyanova \\ Astrakhan State Medical University, Russia
}

\begin{abstract}
This article focuses on the influence of cognitive activities of a medical specialist on formation and development of the terminological field "surgical instruments" of the German language. The terminological field "surgical instruments" of the German language was analysed by means of definitional, categorical, conceptual analysis, as well as by means of the method of frame modeling. It was found that the identification of categories of the terminological field "surgical instruments" helps us to understand the correlation of cognitive and linguistic structures, since the form and the content of the term contain information about the mechanism of the process of nomination. Frame is a group of categories and cognitive features. It contains certain terminological units that specify the instrument, indicate the form, size and its other characteristics.
\end{abstract}

\section{Introduction}

In the late 90 s of the 20th century, cognitive terminology studies arose in the framework of cognitive linguistics and general terminology [1]. It was formed as an independent research area and nowadays it keeps developing as part of cognitive linguistics. Cognitive terminology studies consider not only the linguistic competence of the speaker, but also the relationship of the language with cognitive abilities of the person, such as memory, perception, imagination and thinking [2, 3], the inner nature of the term, the problem of representation of knowledge in the term that "is determined by connection with professional communication, professional cognition and professional activity" [4].

Cognitive terminology studies are focused on the research of the correlation of terminologies (a special part of vocabulary for special areas of knowledge), term systems (a number of lexical units consciously constructed for reflection of the system of concepts of a particular theory) and terminological fields (part of a term system, a structured set of special lexical units of certain areas of knowledge; terminoids, proto- and preterms being on its periphery) with the structures of special knowledge behind them. Consequently, terminologies, term systems and terminological fields are studied according to their role in professional cognition and professional activity.

It should be noted that in the basis of cognitive research there are the works of neurophysiologists (L.S. Vygotsky, A.R. Luria, and others) in the field of the nature of human verbal and cogitative activity.

The basis of cognitive terminology studies was founded by scientists (J. Baudouin de Courtenay, V. von
Humboldt, A. A. Potebnya and others) in the XIX - early XX century. They turned to the functional analysis of speech and tried to understand how exactly the thought of the speaker turns into a statement and how the statement perceived by the listener turns into a thought.

So V. von Humboldt did not only regard language as a tool for expressing the thought, but mainly as a means of forming the thought, which influences the process of thinking [5]. This approach to language has become a fundamental one for the development of cognitive research area, since the basis of this area is a new understanding of the functioning of the language. It "not only ... reflects reality or affects this reflection", but it "is a "window» in the mind of a man" as well, so it means that language "can and should be ... considered as a means of access to the mind of a man and to the cognitive processes that take place in his brain" [6], because all the information which is perceived by the person is processed in the language and by means of the language [7].

It must be noted that the cognitive direction also changed the system of views on the term and formed a new conceptual apparatus connected with the problems of cognition and reflection of knowledge in terms: concepts, categories, frames.

Term is considered as a cognitive structure, "an operational unit of thinking that stores and transmits scientific and professional information" [8]. It is a dynamic lexical unit of any field of science, which has a number of functions and which is created to define special concepts. For us it is important that in this definition there are the following signs of the term: its dynamism, belonging to a certain terminological field, the ability to verbalize the cognitive experience of a medical specialist. The term is "dynamic because it is

* Corresponding author: sanya-madzhaeva@yandex.ru 
associated with the process of cognition, and cognitive activity, the process of enriching of the experience and knowledge of a person is boundless" [9].

Category is "one of the cognitive forms of human thinking, which makes it possible to generalize and classify the existing experience, knowledge ..." [10].

Concept is a dynamic mental formation, which is influenced by the national language, knowledge and human experience reflected in the human psyche; in addition, the concept is the result of cognitive activity.

Frame is a script that regulates the process of perception and thinking. It is based on stored data structures, by means of which a person realizes special information. At the upper level of the frame, there is a hyperframe, at the lower levels - the subframes of the first, second, third (etc.) levels. The number and volume of subframes of different levels, which follow the hyperframe, depend on the cognitive base of the specialist, his knowledge and experience.

\subsection{Materials and methods}

In this paper, the terminological field "surgical instruments" of the German language was analysed by means of definitional, categorical, conceptual analysis, as well as the method of frame modeling. The material for the study is simple, complex terms and terminological word-combinations, which belong to the terminological field "surgical instruments" in the German language.

\section{Results}

The formation of the terminological field "surgical instruments" in the German language is associated with the origin of surgery. It had been formed over a long period of time, which was due to a number of extralinguistic (the age of surgery as a field of medicine; the specifics of the periods of science development affecting the semantics and structure of terms; the features of the origin of surgery; the country in which science develops in a certain period that explains the existence of borrowed words; the development of the purism; consolidation of the country's priority; interaction of surgery with other sciences; the amount of knowledge of a specialist who nominates surgical instruments; technical progress) and linguistic factors (the deepening of differentiation in the meanings of synonyms; the use of abbreviations and apocopic terms; the presence of a large number of term formations).

The professional specificity of the terminological field "surgical instruments" in the German language is reflected in categories and concepts.

Analysis of the works of scientists (E.V. Bekisheva, 2007; N.N. Boldyrev, 2006, 2011; O.Ya. Ivanova, 2004; E.S. Kubryakova, 1997, 2004; V.F. Novodranova, 1997; E.A. Sloeva, 2007) demonstrated that the person in the process of analysis and generalization distributes the knowledge he has in groups, so he categorizes his knowledge $[6,11-16]$. This is caused by the necessity to group the objects that we comprehend as similar or dissimilar in some way to the best example of an object, which we know.

In the works on medical terminology, it is proved that the category of space is the main category of medical terminology, because it has "pragmatic significance, which is explained by the need to accurately indicate the specific shape and size, location and interposition of organs, tissues and body systems" [15].

In the terminological field "surgical instruments", the category space is a categorizing and classifying one, which is verified by the need to indicate 1) place of surgical handle (die Herzpunktionsnadel - needle for cardiocentesis), 2) place of tissue extraction for its further diagnosis (die Nadel für bronchiale Biopsie needle for bronchial biopsy), 3) place for an implant (das Herzimplantat - heart implant).

Moreover, any surgical instrument is an object used for surgical handle. So in the terminological field "surgical instruments" of the German language, it is necessary to distinguish the category object (as a part of space) expressed by lexical units representing surgical instruments (das Messer - surgical knife, die Nadel needle, etc.)).

The designation of spatial relations in the terminological field "surgical instruments" in the German language has functional significance. Terms of the studded terminological field mark the following characteristics:

form (randgebeugte Moskitoklemme - curved on edge haemostatic "Mosquito" forceps, flächengebeugte Moskitoklemme - curved on flat haemostatic "Mosquito" forceps, a gerade Moskitoklemme - straight haemostatic "Mosquito" forceps);

size (großes Amputationsmesser - large amputating knife, kleines Amputationsmesser - smallamputating knife, mittleres Amputationsmesser - amputating knife of middle size);

quality (atraumatische Nadel - atraumatic needle, stechende Nadel - pricking needle, durchstechende Nadel - piercing needle, schneidende Nadel cuttingneedle);

time or duration of use of surgical instrument (der Verweilkatheter - permanent catheter, zeitweiliger Katheter - temporary catheter);

quantity (der Dreiflanscherweiterer - three-paddle dilator, die Dreispurknochenhaltezange - three-pronged bone forceps, chirurgische Mehrzahnpinzette - thumb serrated forceps).

In German terminology in general and in the terminological field "surgical instruments" in particular there is the category genus. All nouns in German have certain grammatical gender. In the analyzed terminological field, there are the terms in which semantics gender characteristics were found (direkte Harnröhrenbougie für Frauen - female strait urethral bougie, gebeugte Harnröhrenbougie für Männer - male curved urethral bougie). In these examples, we distinguish biological category genus. Consequently, the category genus of the terminological field "surgical instruments" in German can be considered as a classifying and categorizing one. 
According to their functional purposes [17-19], surgical instruments are divided into the following groups: das Schneidinstrument - cutting instrument, stechendes Instrument - pricking instrument, abdrängendes Instrument - instrument for moving aside, etc. According to these characteristics, we identify the category function.

Thus, in the terminology field "surgical instruments" of the German language, nine categories are identified: space, object, form, size, function, quality, time, quantity, genus (grammatical and biological).

According to the results of the research, each category is ordered by a series of cognitive features that form the content of the concept. For example, category object is ordered by the following cognitive features instrument, apparatus, device, product.

Some terms can represent simultaneously several categories, which are represented by the cognitive features. For example, the term direkte Harnröhrenbougie für Frauen (female strait urethral bougie) represents four categories: 1) category "object" with cognitive feature instrument, 2) category "quality" with cognitive feature instruments for probing, 3) category "gender" with cognitive feature female, 4) category "space" with cognitive feature place of using (urethra), 5) category "form" with cognitive feature direct. This "integration" of cognitive features, expressed in the one term [11], reflects the complex semantics of the term and indicates that the nomination is a complex, multi-level process carried out by means of the cognitive activity of a specialist.

In the analysed terminological field, the concept surgical instruments is verbalized in terms that fix professional knowledge and experience. Cognitive features of categories "object" (instrument), "function" (purpose of using of surgical instruments), "genus" (grammatical) form the core of this concept. Periphery includes the cognitive features of categories "form" (gebeugte Harnröhrenbougie - curved urethral bougie), "size" (mittleres Amputationsmesser amputating knife of middle size), "quality" (harte Klemme - stiff forceps), "space" (die Magenquetsche stomach clamp), "time" (zeitweiliger Katheter temporary catheter), "quantity" (mehrteilige Spritze sectional syringe), biological "genus" (die Harnröhrenbougie für Männer - male urethral bougie).

Identified categories and cognitive features allow us to understand the specificity of the term chirurgisches Instrumentarium and construct the frame with the following structure (Fig. 1).

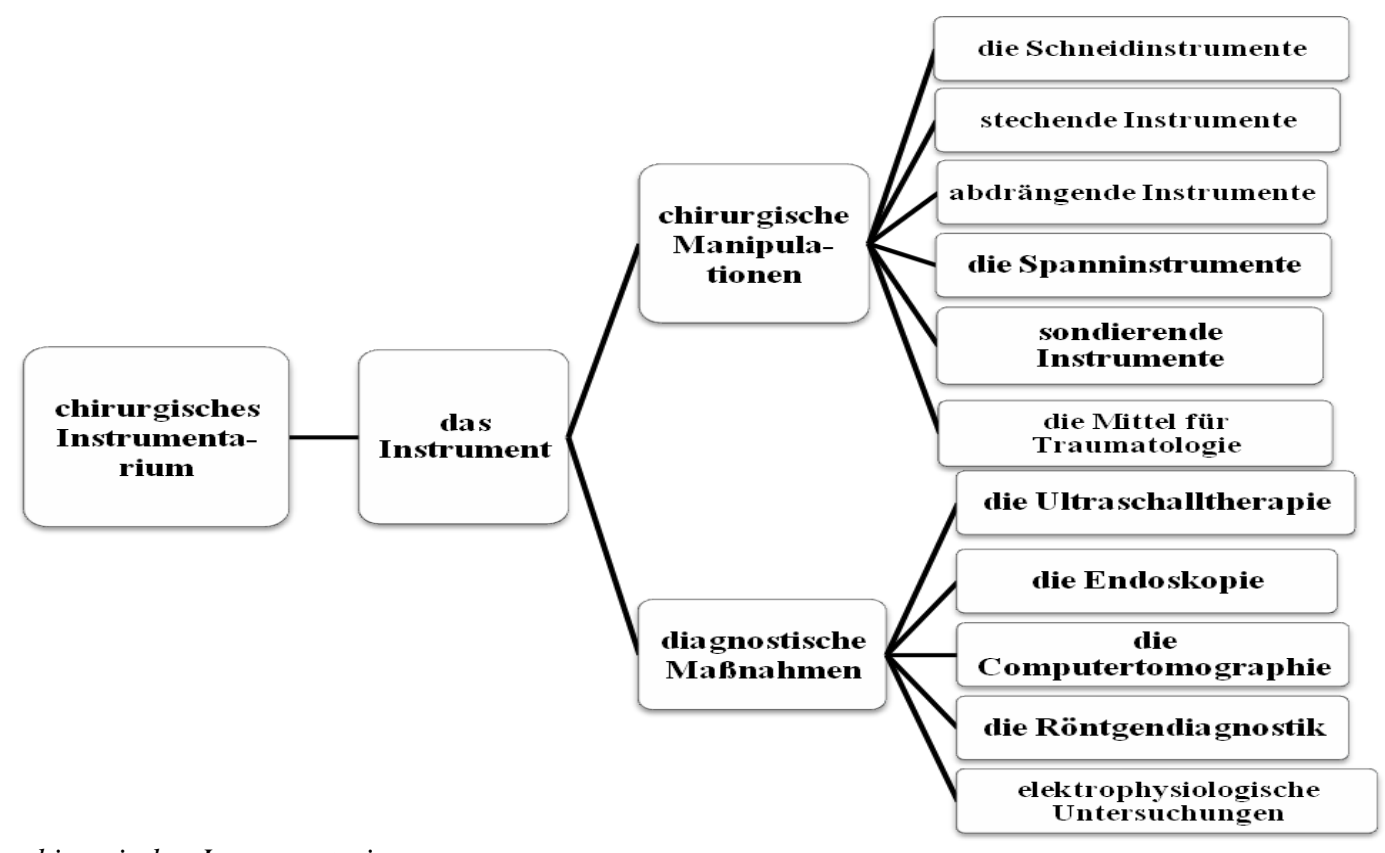

Fig. 1. Frame chirurgisches Instrumentarium.

At the upper level there is the hyperframe chirurgisches Instrumentarium. The results of the analysis of the definitions of the term surgical instruments, which are given in books, dictionaries and encyclopedias of Russian and German publications, show that surgical instruments are a set of instruments used during surgical manipulations and diagnostic examinations. The cognitive features of the analyzed concept - "set of instruments", "surgical manipulations", "diagnostic examinations" - allow distinguishing three levels in the structure of the hyperframe subframes: one subframe of the first level das Instrument which includes two subframes of the second level-chirurgische Manipulationenand diagnostische Maßnahmen.

Subframe of the second level diagnostische Maßnahmen consists of five subframes of the third level - die Ultraschalltherapie, die Endoskopie, die Computertomographie, die Röntgendiagnostik, elektrophysiologische Untersuchungen.

According to the classification of surgical instruments for functional purposes, that is given in National Standards (GOST) 19126 - 2007, the book of

* Corresponding author: sanya-madzhaeva@yandex.ru 
M. Liehn and H. Schlautmann "1x1 der chirurgischen Instrumente. Benennen, Erkennen, Instrumentieren" and others, the subframe of the second level chirurgische Manipulationen can be divided into six subframes of the third level - die Schneidinstrumente, stechende Instrumente, abdrängende Instrumente, die Spanninstrumente, sondierende Instrumente and die Mittel für Traumatologie.

The previously identified categories and cognitive features are verified in the frame surgical instrumentation. Subframes of the second and third levels of the hyperframe surgical instruments are represented by the categories "object", "function", "genus" (grammatical) and the cognitive features instrument, product, purpose of using of surgical instruments, female, neuter gender.

Each subframe of the third level also has a complex structure and is the basis for further classification of surgical instruments. Subframes of the third level are the tops of groups of subsequent hierarchical levels.

The complex structure of the subframes of the third level will be analysed by the example of the classification of the subframe die Schneidinstrumente (cutting tools) (Fig. 2).

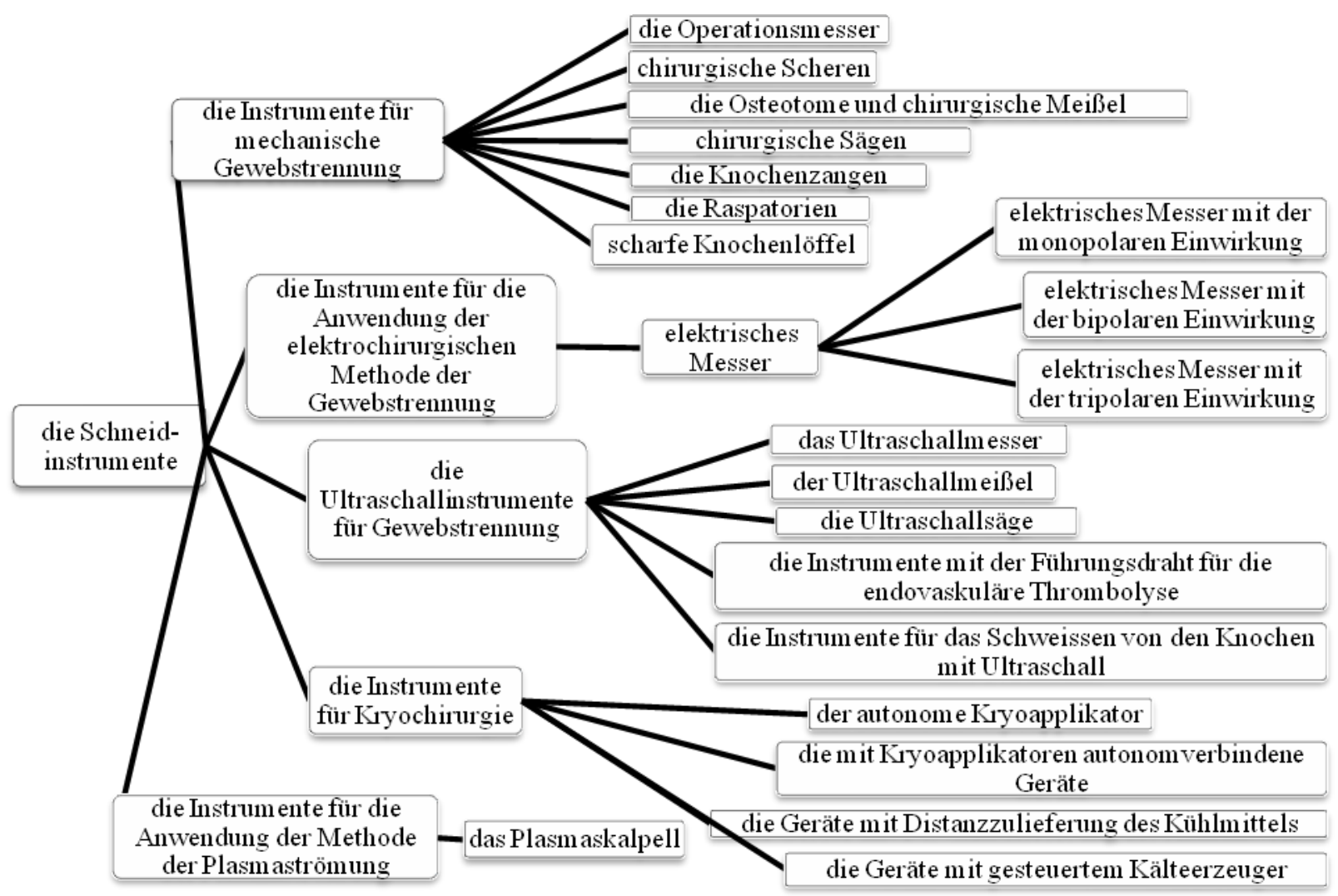

Fig. 2. Frame die Schneidinstrumente

Subframe die Schneidinstrumente was formed due to account the analyzed material and the specificity of the term die Schneidinstrumente (cutting instruments).

At the upper level of the frame there is the hyperframe die Schneidinstrumente. It includes five subframes of the first level - die Instrumente für mechanische Gewebstrennung, die Instrumente für die Anwendung der elektrochirurgischen Methode der Gewebstrennung, die Ultraschallinstrumente für Gewebstrennung, die Instrumente für Kryochirurgie, die Instrumente für die Anwendung der Methode der Plasmaströmung.

The subframes of the first level, taking into account the type, form, quality, size, functional principle of the use of surgical instruments, can be divided into a number of subframes of the second level. The subframe of the first level die Instrumente für mechanische Gewebstrennung contains seven subframes of the second level - die Operationsmesser, chirurgische Scheren, Osteotome und chirurgische Meißel, chirurgische Sägen, die Knochenzangen, die Raspatorien, scharfe Knochenlöffel. These subframes of the second level are represented by the categories "object", "function", "genus" (grammatical), "quality" and the cognitive features instrument, purpose of using of surgical instruments, masculine, feminine, neuter gender, sharp. Each subframe of the second level is the basis of groups of subsequent hierarchical levels.

So the subframe of the second level elektrisches Messer is identified in the subframe of the first level die Instrumente für die Anwendung der elektrochirurgischen Methode der Gewebstrennung, which has, according to the types of electrical effect on the tissue, subframes of the third level elektrisches Messer mit der monopolaren Einwirkung, elektrisches Messer mit der bipolaren Einwirkung, elektrisches Messer mit der tripolaren 
Einwirkung. These subframes of the third level are represented by the categories "object", "function", "genus" (grammatical), "quality" and the cognitive features knife, purpose of using of surgical instruments (monopolar, bipolar, tripolar exposure), neuter gender, electro. Electric knives of each type have their own characteristics. Thus, the monopolar regimen is used for coagulation and dissection of tissues, which are performed by hooks with L-shape, needle-shape, diskshaped, ball-shape. The choice of the shape of the working parts of the electrodes depends on the operation. Taking into account the peculiarities of the types of the electric knife, it is possible to say that each subframe of the third level is the top of the subframes of the subsequent levels, and the structure of the frame can be enlarged.

According to classification of instruments we identified in the subframe of the first level die Ultraschallinstrumente für Gewebstrennung five subframes of the second level - das Ultraschallmesser, der Ultraschallmeißel, die Ultraschallsäge, die Instrumente mit der Führungsdraht für die endovaskuläre Thrombolyse and die Instrumente für das Schweissen von den Knochen mit Ultraschall. They are represented by the categories "object", "function", "genus" (grammatical), "quality" and the cognitive features instrument, purpose of use of surgical instrument (tissue separation, endovascular destruction, "welding"), masculine, feminine, neuter gender, ultrasound.

The subframe of the first level die Instrumente für Kryochirurgie reflects the structure and properties of this type of instruments. Since the devices for cryodestruction (das Gerät für Kryoablation) are "devices for delivering coolant to the tips of instrument to effect on a limited area of tissue" [20], we included four subframes of the second level in this subframe - der autonome Kryoapplikator, die mit Kryoapplikatoren autonomverbindene Geräte, die Geräte mit Distanzzulieferung des Kühlmittels and die Geräte mit gesteuertem Kälteerzeuger. These subframes of the second level are represented by the categories "object", "function", "genus" (grammatical), "quality" and the cognitive features apparatus, applicator, purpose of using of surgical instruments (tissue separation, endovascular destruction), masculine, neuter gender, autonomous, cryo, remote cooling agent supply, controlled cold generator.

The subframe of the first level die Instrumente für die Anwendung der Methode der Plasmaströmung is ordered by the subframe of the secondlevel das Plasmaskalpell, represented by the categories "object", "function", "genus" (grammatical), "quality" and the cognitive features instrument (scalpel), purpose of use of surgical instrument (tissue separation), neuter gender, plasmatic. A plasma scalpel is an instrument that makes it possible to use energy of a new type - the energy of plasma flows formed with the help of special generators plasmatrons. There are several types of plasma scalpels: a scalpel with the energy of low-temperature plasma, an air-plasma scalpel-coagulator-stimulator. Therefore, the specificity of this surgical instrument indicates the possibility of identification of subframes of the third level.

It should be noted that constructed frames surgical instruments and cutting instruments are not universal. The frame is not static; it is dynamic and can change in connection with the cognitive base of a specialist, his experience, knowledge, intuition, type of operation, the economic base of a hospital. Frames surgical instruments and cutting instruments demonstrate "transience, dynamics and creative organization" [21] of the terminological field "surgical instruments" of the German language.

\section{Conclusions}

It was found that the identification of categories of the terminological field "surgical instruments" lets understand the correlation of cognitive and linguistic structures, since the form and the content of the term contain information about the mechanism of the process of nomination. These psychological and mental processes are verbalized in the term. Concepts that perform classifying, categorizing functions have linguistic expression, which helps to present knowledge about surgical instruments.

Frame is a group of categories and cognitive features, united by a hierarchy and expressed in terms. Each subframe contains certain terminological units that specify the instrument, indicate the form, size and other its characteristics. Thanks to frame, we can more clearly represent the purpose of the surgical instrument. The structure of knowledge (in the form of a frame) is the basis for the subsequent enlargement, enrichment of knowledge.

\section{References}

1. V.F. Novodranova, Terminology and knowledge: materials of the 2nd International Symposium (Moscow. May 21-22, 2010). 24-30. (2010)

2. M. Schwarz, Einführung in die Kognitive Linguistik. (Francke, Tübingen, Basel, 1996)

3. D. Geeraerts, H. Guyckens, Cognitive Linguistics. (University Press, Oxford, 2007)

4. Yu.N. Revina, [Electronic resource] http://elar.urfu.ru/bitstream/10995/25318/1/ avfn 2013 38.pdf. (Date of access: 28.08.2016)

5. V. von Humboldt, Selected papers in linguistics. (LLCIG "Progress", Moscow, 2000)

6. E.S. Kubryakova, Language and Knowledge: On the way of getting knowledge about language: Parts of speech from the cognitive point of view. The role of language in the knowledge of the world. (Languages of Slavic culture, Moscow, 2004)

7. E.I. Golovanova, Introduction into cognitive science of terminology. (Flinta: Science, Moscow, 2011)

8. S.I. Madzhaeva, Terms in communicative field: materials of the scientific seminar. 237-241. (2017) 
9. T.V. Lukoyanova, Linguistics of the 21st Century: Traditions and Innovations: a collected works based on the materials of the Second international scientific conference in memory of professor V.V. Lazarev. 76-83. (2017)

10. E.S. Kubryakova, V.Z. Demyankov, Yu.G. Pankrats, L.G. Luzin, A Short Dictionary of Cognitive terms. (Moscow Lomonossov's State Univ. Press, Moscow, 1997)

11. E.V. Bekisheva, Forms of language presentation of gnoseological categories in clinical terminology. Abstract of thesis of doctor of philology (Moscow, 2007)

12. N.N. Boldyrev, Bulletin of Chelyabinsk State University. Philology. Art history. 33 (248). 11. (2011)

13. N.N. Boldyrev, Questions of Cognitive Linguistics. 2. 5. (2006)

14. O.Ya. Ivanova, Linguistic and cultural specifics of the word-formation category of locality (on the material of the Russian and English languages): thesis of philology sciences candidate (Stavropol, 2004)

15. V.F. Novodranova, To the jubilee of the scientist: a collection of scientific works devoted to the anniversary of E.S. Kubryakova. 83. (1997)

16. E.A. Sloeva, Cognitive-communicative approach to the description of anatomical object: thesis of philology sciences candidate (Samara, 2007)

17. National Standards (GOST) 25725 - 89. Medical metal tools. General technical conditions. [Electronic resource] http://docs.cntd.ru/document/ gost-25725-89 (Date of access: 03.03.2015) (Standard in form Press, Moscow, 1989)

18. National Standards (GOST) 25725 - 89. Medical instruments. Terms and definitions. (Standard in form Press, Moscow, 2007)

19. M. Liehn, H. Schlautmann, $1 x 1$ der chirurgischen Instrumente. Benennen, Erkennen, Instrumentieren. (Springer-Verlag, Berlin, Heidelberg, 2011)

20. G.M. Semenov, Modern surgical instruments. (Piter, St. Petersburg, 2006)

21. L.A. Manerko, Text and Discourse: Traditional and Cognitive-Functional Aspects of Research: Collection of Scientific Works. 17. (2002) 